\title{
The commercialization of research results in medicine
}

\author{
Justyna Ożegalska-Trybalska
}

Intellectual Property Law Chair, Jagiellonian University, Krakow, Poland

The commercialization of research results, understood as their use and dissemination to other entities in a manner that allows for financial gain. In this regard, the general rules that apply to the commercial exploitation of economic and transferable intellectual property rights protecting the results of scientific activities are supplemented with specific statutory regulations. They define the procedure for the commercialization of the results of scientific activities carried out in universities and research institutes, the rights and obligations of researchers in the field of commercialization and the rules for distribution of profits from commercialization between the entity and the single author or members of the research teams.

Key words: research results, commercialization, distribution of profits from commercialization, intellectual property management policy

\section{Introduction}

Scientific research is an indispensable element of modern medicine which seeks increasingly effective ways of solving aging societies' health problems, treating civilization diseases and combating threats to public health. A lot of groundbreaking applied scientific research is carried out at medical universities and research institutes. Their results are the basis for developing new treatments, products, devices and medical technologies [1]. Apart from scientific publications, the number of patent applications and implementations based on the research results constitutes the criterion of parametric evaluation of scientific units and periodic evaluation of researchers.

Despite some freedom in the management of research results, and the acquisition of rights to them, the procedure and the distribution of profits from commercialization are subject to specific statutory regulations and/or rules applicable to funds or grants from which research activities are financed. The the knowlege of these regulations is essential for the effective and profitable management of intellectual property related to research results in scientific units, research teams and joint projects carried out by clinical departments and entities marketing medical products ready for market sales.

\section{Model for commercialization of scientific research and development results}

The protection of research results in scientific units researching the field of medical sciences is subject to the general provisions of the Act of 4 February 1993 on Copyright and Related Rights [2] and the Act of 20 June 2000 Industrial Property Law [3]. They concern, in particular, the acquisition by these units as an employer of author's economic rights and industrial property rights to intellectual creations. As regards employee's inventions, the law provides the possibility of participation of the author-employee in the benefits obtained from the use of the invention (sale or licensing of rights to the invention). The regulations also include rules of transfer and licensing of rights to such results, which, after valuation, may also constitute a contribution in kind to a capital company.

Specific rules concerning the management and commercialization of scientific activity results at universities are provi-

\section{How to cite:}

Ożegalska-Trybalska J. The commercialization of research results in medicine. NOWOTWORY J Oncol 2021; 71: 129-131. 
ded by the Act of 20 July 2018. The Law on Higher Education and Science [4] and the Act on Research Institutes of 30 April 2010 on Research Institutes [5], apply to research institutes supervised by the Ministry of Health. The regulations as mentioned above refer to the "results of scientific research and development works and the know-how related to these results", or, a collective term "results of scientific activity", covering all types of such results. These terms also apply to inventions and copyright works resulting from development work. Results of scientific activity in this sense do not involve scientific work (scientific publications, lectures, conference speeches), as well as the following not protected by intellectual property rights: scientific findings, clinical data, discoveries, results of clinical trials "as such". These creative results are generally outside the scope of commercialization processes.

The process of transferring the results of scientific activity to practice comprises:

- direct commercialization, i.e. the sale of results, making these results or know-how available for use, in particular on the basis of a license, lease and rental agreement; and - indirect commercialization, including the acquisition or purchase of shares or stocks in companies in order to implement the results of scientific activity in exchange for the rights to such results and to generate income from this.

Public universities can carry out indirect commercialization through a dedicated university special purpose company (e.g. SYNERGIA-WUM Sp. z o. o; the Centre for Innovative Technologies of the Pomeranian Medical University). With the consent of the Minister of Health, medical research institutes can also establish capital companies and take up or acquire shares and stocks for the purposes of commercialization, conducting activities in the field of technology transfer and dissemination of science, as well as obtaining funds for statutory activities. The units responsible for supporting the commercialization processes in research units are technology transfer centers.

Internal regulations for the management of copyright, industrial property rights and principles of commercialization are an essential tool for supporting commercialization processes. They regulate the principles, procedure for the commercialization of research results created in the research unit and in cooperation with external entities in the framework of joint research projects or commissioned work. Adoption of such regulations is the responsibility of all research units. In the case of public medical higher education institutions and research institutes, they should define:

- the rights and obligations of the units, employees and doctoral students as regard the use of copyright, related rights and industrial property rights;

- the principles of remuneration of authors;

- the principles of distribution of funds obtained from commercialization;

- the principles and procedures of commercialization of research and development results and the know-how related to these results;
- the principles of using the unit's property used for the commercialization of research results.

The rules of procedure should be effectively notified to employees and form part of their employment contracts.

\section{Rights and obligations of the research unit and employees}

The statutory model for the commercialization of research and development work in public universities covers the results of employees'scientific activity obtained in the performance of their duties, to which the research unit, as the employer, is entitled to intellectual property rights. Firstly, its essence is the obligation of the entity to decide on the commercialization of such results within a specified time. Secondly, the obligation to contractually transfer the rights to such results to the employee for a statutorily specified amount if the entity is not interested in commercialization, but the employee declares a desire to acquire them. Remuneration for the transfer of rights cannot be higher than $5 \%$ of the average salary in the national economy (about 200 PLN). This is a desirable solution for the creator-employee, who, for a small amount, can obtain the rights to research results and decide on their further commercial exploitation, e.g. as part of their business activities.

At the same time, public universities'employees have obligations related to the statutory procedure for the acquisition and commercialization of rights to research and development results. These include:

- reporting the results of scientific research and development works and the know-how related to these results in the procedure specified in internal regulations,

- transferring all available information and technical experience needed for commercialization,

- maintaining the confidentiality of these results.

\section{Sharing commercialization revenue}

An essential aspect of the statutory procedure for the commercialization of research and development results is creating a financial incentive to develop solutions that can be implemented in practice. In the case of obtaining economic benefits from the commercialization of research results at a public university (e.g. the sale or licensing of an invention resulting from scientific research), the creator-employee is guaranteed by law the right to participate in benefits obtained on this account. In this case, the employee is entitled to no less than $50 \%$ of the value of the commercialization funds. It can be reduced by no more than $25 \%$ of the costs directly related to it (Article 155 of the Act on Higher Education and Science). If a research team obtained the commercialized results, the indicated minimum share of $50 \%$ refers to the total remuneration and the allocation of these funds. In a situation where commercialization is carried out by an employee to whom the rights to research results have been transferred on the basis of an agreement, the employee is required to pay the university $25 \%$ of the value 
of such benefits, reduced by no more than $25 \%$ of the costs incurred by the employee in direct relation to that activity. "Costs directly related to commercialization", include external costs, particularly the costs of legal protection, expert opinions, assessment of the value of the object of commercialization and official fees incurred to obtain protection (particularly patent protection of the invention as an ordinary object of commercialization). The right of an employee and the higher education institution to remuneration for the benefits from commercialization shall last five years from the date of the first benefit derived from commercialization. During this period, the right to claim remuneration shall be vested in the creator of the results regardless of whether or not he/she continues to have the status of an employee of the entity. Therefore the right can also be executed after the termination of employment.

\section{The commercialization of research results financed from external sources}

The described statutory rules for commercialization of research and development results laid down in the Act on Higher Education and Science do not apply to cases where the scientific activity which led to the creation of the results was conducted on the basis of an agreement with a party financing or co-financing this activity and this agreement includes an obligation to transfer the rights to the results of scientific activity to this party or to another entity. This also applies to research conducted with the use of funds, the rules of granting or use of which determine, in an autonomous way, the manner of disposing the results of scientific activities and the know-how related to these results (e.g. research funds from the National Centre for Research and Development (NCBiR), the National Science Centre (NCN), European Research Council (ERC) grants, EU research grants [6].

\section{Conclusions}

The search for new ways to effectively support health care and the treatment of civilization diseases, new possibilities of financing research in medicine, increasing cooperation between clinical units and entities marketing final medical products is conducive to the intensification of commercialization processes of research results. More and more often, they are successfully commercialized through companies dedicated to this purpose (e.g. PolTREG of the Medical University of Gdansk commercializing innovative therapy for diabetes, by using T-regulatory lymphocytes taken from the patient's blood). There are also examples of successful licensing on commercial terms (e.g. a license to iQure Pharma for a patent protecting the Jagiellonian University invention "Modified amino acid derivatives for treatment of neurological diseases and selected psychiatric disorders" [7]).

The interest of scientific employees in the implementation of their research results is also increasingly influenced by the scoring of such achievements in the periodic evaluation of scientific employees' activity and the scientific output assessed in the procedures for obtaining scientific degrees and titles.

Due to the statutory regulation of the commercialization of research and development results, public universities, research institutes and their researchers are bound by the rights and obligations arising from the applicable legislation. They can be specified or supplemented in internal regulations on the management of copyright and industrial property rights and commercialization. Compliance with these regulations is subject to control by the authorities supervising these institutions [8].

An important incentive to conduct research that has scientific value and can be applied in practice is the right to participation in the benefits of commercialization of such results. There is also the possibility to purchase rights by the employee from the university for a fixed lump sum in order to further commercialization. It can be successfully conducted through a dedicated company developing and offering medical products or services based on such results on commercial terms.

In the case of research and development results obtained under grants, multicenter or international projects or cooperation with external entities, the rules for the acquisition and commercialization of rights to such results may be the subject of autonomous regulations, which will be decisive in terms of the management of the results of such projects.

\section{Conflict of interest: none declared}

\author{
Justyna Ożegalska-Trybalska \\ Jagiellonian University \\ Intellectual Property Law Chair \\ ul. Józefa 19 \\ 31-056 Kraków, Poland \\ e-mail:j.ozegalska-trybalska@uj.edu.pl
}

\section{Received: 9 Mar 2021}

Accepted: 15 Mar 2021

\section{References}

1. Trzmielak D, Wojciechowicz J. Transfer biotechnologi i rola naukowca w komercjalizacji wyników badań na przykładach spółek spin-off / spin-out - Centrum Badań DNA sp. z o.o. oraz Inno-Gene s.a. Innowacje i komercjalizacja w biotechnologii. 2013: 191-206, doi: 10.18778/922375-5-6.11.

2. Dz. U. z 2019 r., poz. 1231

3. Dz. U. z 2021 r. poz. 324.

4. art. 148-158; t.j. Dz. U. z 2020 r. poz. 85

5. $\quad$ art. 17 ust. 5, art. 24 a, Dz. U. z 2020 r. poz. 1383.

6. Wojakowski W. Finansowanie badań naukowych w medycynie sercowo-naczyniowej (sukcesy, perspektywy i wyzwania). Kardiologia Inwazyjna. 2018; 13(1): 13.

7. Patent nr P 429656, twórcy wynalazku: K. Kamiński, M. Abram, M. Jakubiec, A. Rapacz, Sz. Mogilski, G. Latacz, M. Struga.

8. Komercjalizacja wyników badań naukowych. Informacja o wynikach kontroli, 2016. https://www.nik.gov.pl/plik/id,10797,vp,13130.pdf. 